\title{
PELATIHAN PENGEMBANGAN CONTENT E-LEARNING UNTUK GURU IPA SE-JALUKO
}

\author{
H Pathoni ${ }^{1 *}$, F B Pujaningsih², M Hendri ${ }^{3}, \mathrm{Maison}^{4}, \mathrm{Nehru}^{5}$ \\ ${ }^{1 *}$ Program Studi Pendidika Fisika, Universitas Jambi \\ ${ }^{2}$ Program Studi Pendidika Fisika, Universitas Jambi \\ ${ }^{3}$ Program Studi Pendidika Fisika, Universitas Jambi \\ ${ }^{4}$ Program Studi Pendidika Fisika, Universitas Jambi \\ ${ }^{5}$ Program Studi Pendidika Fisika, Universitas Jambi \\ Corresponding author : \\ E-mail : haerul_pathoni@unja.ac.id
}

Diterima 25 September 2019, Disetujui 7 Oktober 2019

\begin{abstract}
ABSTRAK
Dalam proses pembelajaran, guru dituntut dalam memilih metode yang tepat. Apabila metode pembelajaran yang digunakan bersifat konvensional maka dapat menurunkan semangat dan minat belajar siswa di sekolah. Permasalahan dalam pembelajaran di sekolah sering ditemui khususnya ketika siswa mengalami kesulitan dalam belajar. Solusi dari permasalahan tersebut adalah dengan melaksanakan pembelajaran yang lebih menarik menggunakan media e-learning berbasis edmodo.Tujuan utama dari media ini adalah untuk meningkatkan aktivitas dalam pembelajaran karena edmodo hampir sama dengan facebook sehingga diharapkan dengan penggunaan edmodo siswa akan lebih merasa senang dalam pembelajaran fisika dan materi akan lebih mudah untuk dipahami. Tahap persiapan dimulai dari observasi di beberapa sekolah di Kecamatan Jambi Luar Kota untuk mengetahui sejauh mana penggunaan media pembelajaran oleh guru IPA serta koordinasi dengan MGMP IPA Rayon Jaluko Kab. Muaro Jambi, Provinsi Jambi. Tahap pelaksanaan yaitu pelatihan pengembangan content e-learning untuk pembelajaran IPA menggunakan edmoda. Hasil pengabdian memperlihatkan guru antusias dalam mengikuti pelatihan pengembangan content e-learning. Beberapa pertanyaan diajukan guru terkait bagimana cara penggunaan edmoda. Secara keseluruhan dapat dikatakan tujuan pengabdian tercapai yaitu dengan ditandai dengan antusias guru, berbagai masalah pengembangan content e-learning dapat diselesaiakan dan guru dapat menggunakan edmoda dengan baik dan benar.
\end{abstract}

Kata kunci: e-learning, edmodo, Pembelajaran IPA.

\begin{abstract}
In the learning process, teachers are required to choose the right method. If the learning method used is conventioanl, it can reduce student's enthusiasm and interest in learning at school. Problem in learning at school are often encountered especially when students experience learning difficulties. The solution to these problem is to carry out more interesting learning using edmodo based e-learning media. The main pupose of this media is to increase learning activities because edmodo is almost the same as facebook so hopefully with use of edmodo students will be more happy in physics learning and material will be easier to understand. The preparation phase start from obeservation in several school in the district of Jambi Luar Kota to find out the extent of the use of learning media by science teachers as well as coordination with the MGMP IPA Rayon Jaluko Districts Muaro Jambi, Jambi Province. The implementation phase is training in developing e-learning content for science learning using edmodo. The result of community service show that the teacher is enthusiastic in participating in training in developing e-learning content. Some questions were raised by teacher regarding how to use edmodo. As a whole, it can be said that purpose of community service is achieved, which is marked by the enthusiasm of the teacher, various problem in developing elearning content can be completed and the the teacher can be use edmodo properly and correcly.
\end{abstract}

Keywords: e-learning, edmodo, science learning 


\section{PENDAHULUAN}

Pembelajaran merupakan suatu sistem atau proses membelajarkan pembelajar yang direncanakan, dilaksanakan, dan dievaluasi secara sistematis agar pembelajar dapat mencapai tujuan-tujuan pembelajaran secara efektif dan efisien [Komalasari, 2013]. Dalam menciptakan proses pembelajaran yang menyenangkan bagi siswa, guru selaku fasilitator dituntut dapat memilih media pembelajaran yang tepat. Permanfaatan teknologi informasi dapat mendorong terciptanya berbagai media pembelajaran untuk meningkatkan kualitas pendidikan. Kecamatan Jambi Luar Kota merupakan salah satu kecamatan yang berada di kabupaten Muaro Jambi. Di Kabupaten Muaro Jambi terdapat suatu Universitas Jambi sebagai instuisi pendidikan terbesar di Provinsi Jambi.

Peningkatan bidang pendidikan yang mencakup kemampuan dan kemahiran guru dalam melaksanakan kegiatan belajar mengajar di kecamatan Jambi Luar Kota dilakukan melalui kegiatan MGMP. Salah satu tempat Kegiatan MGMP guru IPA di kecamatan ini adalah di SMPN 7 Muaro Jambi. Berdasarkan hasil wawancara dengan salah satu guru IPA di kecamatan Jambi Luar Kota bahwa kegiatan belajar belum maksimal memanfaatkan media pembelajaran untuk mendukung kegiatan belajar mengajar di kelas.Penggunaan media pembelajaran yang baik memb eri dampak yang positif bagi siswa terutama dalam meningkatkan motivasi belajar.

Perkembangan teknologi informasi memperkenalkan konsep baru dalam pembelajaran yang dikenal dengan e-learning. Salah satu bentuk pembelajaran e-learning adalah edmodo. Edmodo sangat berguna untuk mengelola pembelajaran di kelas berbasis kelompok dan menjadi proses pembelajaran yang menarik dan menyenangkan. Konten yang terdapat pada media pembelajaran edmodo berupa fitur berbagai materi, penugasan, kuis dan memungkinkan adanya kegiatan diskusi. Hal ini merangsang aktivitas peserta didik menjadi lebih baik. Proses pembelajaran yang dilakukan di dalam kelas merupakan aktivitas mentransformasikan pengetahuan, sikap, dan keterampilan [Yamin, 2007]. Edmodo" merupakan aplikasi yang menarik bagi guru dan siswa dengan elemen sosial yang menyerupai facebook, tapi sesungguhnya ada nilai lebih besar dalam aplikasi edukasi berbasis jejaring sosial ini [Rismayanti, 2012]. Edmodo (dirancang oleh guru) yang juga berbasis cloud kolaborasi merupakan aplikasi yang cukup aman digunakan oleh guru dan siswa. Seorang guru, sekolah, kabupaten/kecamatan dapat dengan mudah mengelolah sebuah sistem yang menyediakan fitur terbaik dan praktis menghilangkan kecemasan terhadap aktivitas yang biasa siswa lakukan dengan internet khususnya facebook.

Dibandingkan dengan media sosial lainnya, Edmodo memiliki beberapa kelebihan antara lain mirip facebook; mudahdigunakan, closed group collaboration; hanya yang memiliki group code yang dapat mengikuti kelas; free, diakses online, dan tersedia untuk perangkat smart phone (android danlphone); tidak memerlukan server disekolah; dapat diakses dimanapun dankapanpun; selalu diupdate oleh pengembang; dapat diaplikasikan dalam satu kelas, satu sekolah, antar sekolah dalam satu kota/kabupaten; dapat digunakan bagi siswa, guru, dan orangtua; digunakan untuk berkomunikasi dengan menggunakan model sosialmedia; learning material, dan evaluasi; mendukung model team teaching, co-teacher, dan teacher collaboration; dan terdapat notifikasi [Priowirjanto dkk (2013]. Oleh karena itu, guru perlu menggunakan dan menerapkan media pembelajaran e-learning berupa edmodo dalam kegiatan pembelajaran.

Berdasarkan uraian permasalahan di atas, maka selaku tim pengabdian masyarakat melaksanakan pengabdian yaitu "Keterampilan mengembangkan Content E-Learning Untuk Guru IPA Se-Jaluko". Dengan adanya kegiatan pengabdian ini diharapkan memberikan kontribusi di dalam peningkatan kompetensi guru-guru anggota MGMP IPA Rayon Jaluko Kab. Muaro Jambi, Provinsi Jambi dalam keterampilan pengembangan e-learning. Melalui kegiatan ini minimal guru-guru dapat menggunakan dan menerapkan media pembelajaran elektronik berupa edmodo selama proses pembelajaran IPA.

\section{METODE PELAKSANAAN}

Kegiatan pengabdian kepada masyarakat dilaksanakan di SMPN 7 Muaro Jambi, Provinsi Jambi. Kegiatan pengabdian terdiri dari tiga kegiatan, yaitu persiapan, pelaksanaan, dan evaluasi. Sasaran dari kegiatan pengabdian kepada masyarakat adalah guru-guru anggota MGMP IPA Rayon Jaluko Kab. Muaro Jambi, Provinsi Jambi. Metode yang digunakan dalam kegiatan pelatihan ini adalah metode ceramah, diskusi, demonstrasi dan tanya jawab. Materi yang disampaikanadalah adalah tentang pengenalan e-learning, cara pengembangan e-learning, dan contoh media 
pembelajaran yang menggunakan e-learning (edmodo).

\section{HASIL DAN PEMBAHASAN}

Kegiatan pengabdian ini dilaksanakan pada hari Selasa tanggal 20 Agustus 2019 yang bertempat di SMPN 7 Kabupaten Muaro Jambi, Provinsi Jambi. Peserta kegiatan pengabdian masyarakat ini terdiri dari dua belas guru-guru anggota MGMP IPA Rayon Jaluko Kab. Muaro Jambi, Provinsi Jambi. Kegiatan pengabdian di awali dengan pembukaan yang langsung dihadiri oleh kepala dinas pendidikan Kab.Muara Jambi dan Dekan FKIP Universitas Jambi.

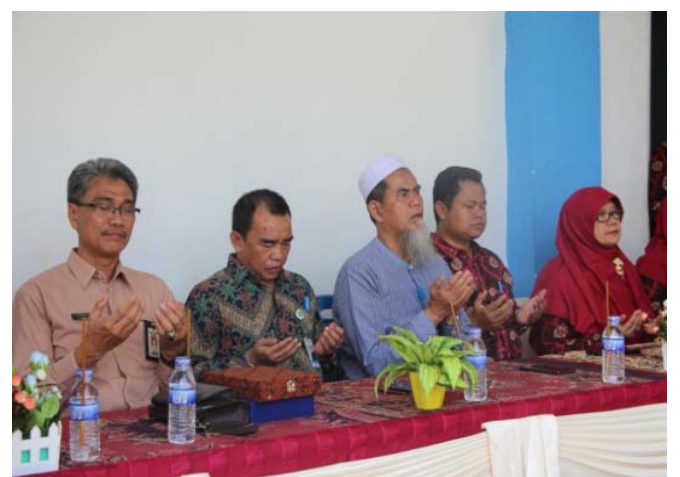

Gambar 1. Kepala Dinas Pendidikan Kab Muara Jambi, Dekan dan Wakil Dekan BAKSI FKIP menghadiri acara pembukaan pengabdian Prodi Pendidikan Fisika FKIP Universitas Jambi

Setelah pembukaan pengabdian, tahap selanjutnya adalah penyampaian materi tentang pembuatan content e-learning oleh tim .

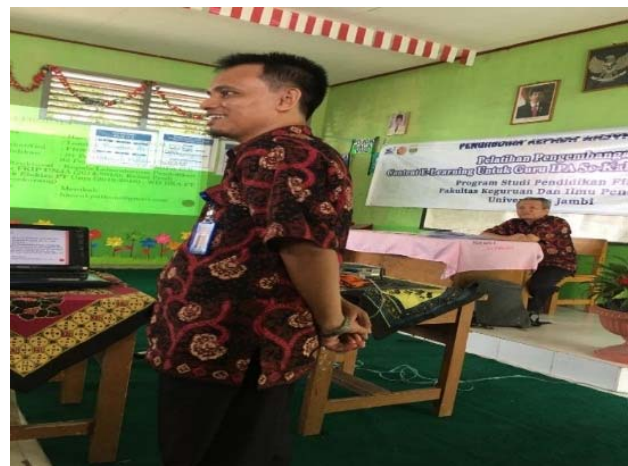

Gambar 2. Tim sedang menyampaikan materi tentang pembuatan content e-learning berbasis Edmodo.

Materi disampaikan dengan bagus menggunakan powerpoint dan melalui laman www.edmodo.com. Edmodo sangat komprehensif sebagai sebuah course management system seperti layaknya Moodle.
Perbedaan pada keduanya adalah aksesnya lebih cepat dan lebih mudah penggunaannya dengan beberapa fitur yang fungsinya sama seperti layaknya sebuah course management system. Edmodo seperti alat bantu lainnya, bisa menjadi hanya sebuah platform online untuk mendorong pembelajaran guru atau dapat menjadi cara lebih kreatif untuk melibatkan para siswa dalam pembelajaran kolaboratif dan kognisi terdistribusi. Platform ini memberikan siswa jalur untuk berinteraksi dengan rekanrekan mereka dan guru mereka dalam suasana akademis. Lebih jauh lagi penggunaan platform ini dapat mengajarkan siswa untuk bagaimana berperilaku secara online dan bertanggung jawab dalam mengatur kegiatan belajar mereka dengan sistem yang keamanannya terjamin [Rismayanti (2012)]. Tampilan awal Edmodo seperti ditunjukkan pada Gambar 3.

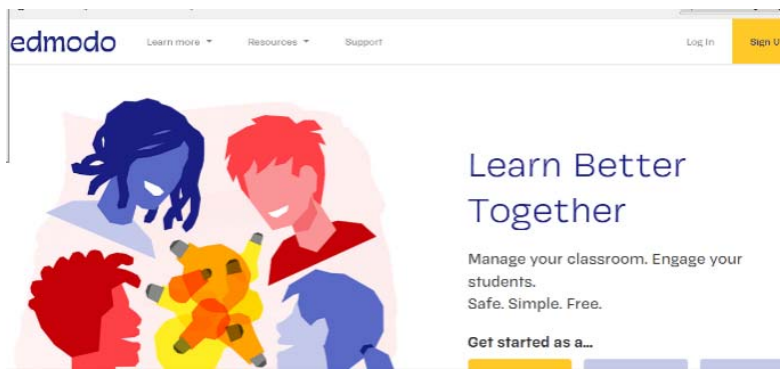

Gambar 3. Akun awal Login Edmodo.

Pada saat proses pengabdian peserta sangat serius dan fokus dalam menerima materi yang disampikan oleh tim pengabdian. Selain itu proses diskusi juga berjalan dengan baik antara tim pengabdian dengan peserta pengabdian. Beberapa peserta pengabdian memberikan pertanyaan kepada tim pengabdian. Pelaksanaan kegiatan pengabdian seperti ditampilkan pada Gambar 4.

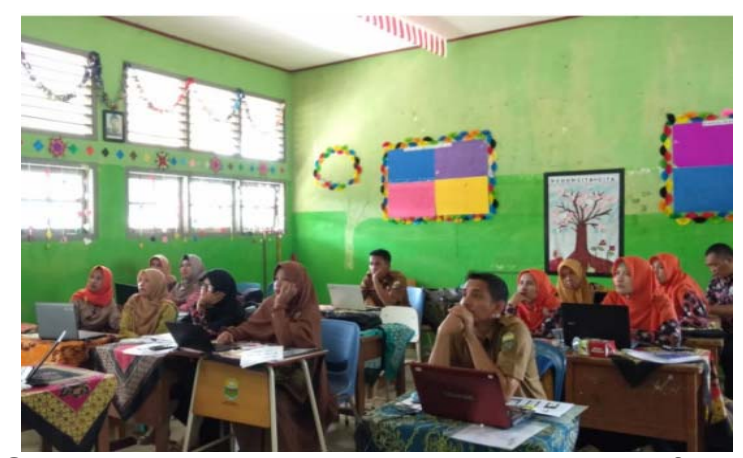

Gambar 4. Peserta pengabdian serius dan focus menerima materi yang disampaikan tim pengabdian. 


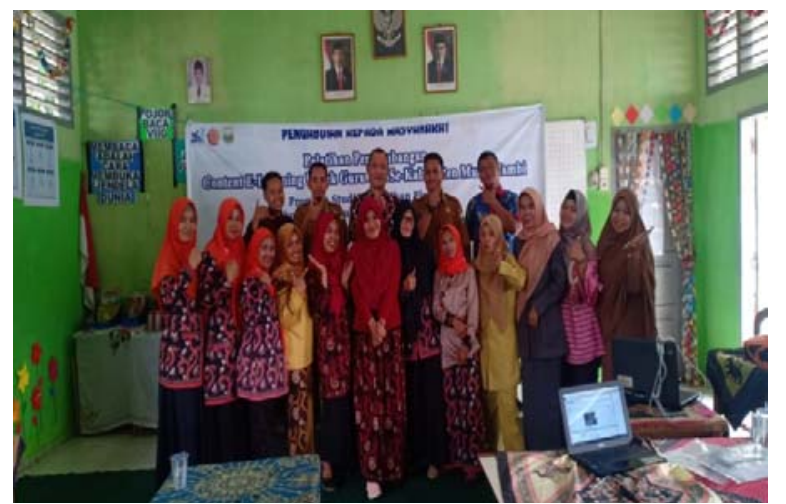

Gambar 5. Foto bersama tim pengabdian dan peserta pengabdian

\section{SIMPULAN DAN SARAN}

\section{Simpulan}

Kesimpulan kegiatan pengabdian kepada masyarakat adalah sebagai berikut :

1. Pengabdian kepada masyarakat dengan judul pengembangan content e-learning untuk pembelajaran IPA menggunakan Edmoda sudah dilaksanakan dengan baik pada tanggal 20 Agustus 2019 di SMP N 7 Muaro Jambi

2. Pengabdian kepada masyarakat dengan judul pengembangan content e-learning diikut oleh dua belas guru anggota MGMP IPA Rayon Jaluko Kab. Muaro Jambi

3. Materi Pengabdian kepada masyarakat dengan judul pengembangan content $e$ learning adalah pengenalan e-learning, cara pengembangan e-learning, dan contoh media pembelajaran yang menggunakan e-learning (Edmodo).

\section{Saran}

Saran pada pengabdian ini perlu sarana dan prasarana yang lebih memadai seperti laptop, wifi ,dan lain-lain. Hal ini karena pada saat pengabdian banyak peserta yang tidak mempunyain laptop dan wifi.

\section{DAFTAR RUJUKAN}

Komalasari, Kokom. (2013). Pembelajaran Kontestual: Konsep dan Aplikasi. Bandung: PT Refika Adiatama.

Priowirjanto, G. (2013). Southeast Asian Ministers Of Education Organization Regional Open Learning Centre.

Rismayanti, Anti. 2012. Mengenal Lebih Dekat Edmodo sebagai Media E-learning dan Kolaborasi. [Online]. Tersedia http://download.smkn1majalengka.sch.id. Dipetik 8 Juni 2018
Yamin, Martinis. 2007.Strategi pembelajaran berbasis kompetensi.Jakarta: GP Press 